(Aus der Ersten medicinisc] in Universitätsklinik des Herrn Geh. Rath Professor Dr. E. v. Leyden zu Berlin.)

\title{
Eine historische Studie über die Entdeckung des Magendie-Bell'schen Lehrsatzes.
}

Von

\section{Dr. Adolf Biekel.}

Dem ungeahnten Aufschwung, den die Physiologie zu Beginn des neunzehnten Jahrhunderts genommen hat, verdankt die gesammte Medicin nicht zum Letzten ihr Emporblühen.

Die Physiologie war die Lehrmeisterin, die aus dem Reiche der Speculation und aus dem Banne einer krassen Empirie die Medicin in die Bahnen exacter, naturwissenschaftlicher Forschung hinlenkte.

Und wenn heute dieses innige Verhältniss der praktischen Medicin zur Physiologie sich zu lockern droht, dann bietet gerade die Jahrhundertwende willkommenen Anlass, der Dienste zu gedenken, die die Physiologie der praktischen Medicin geleistet, und durch die sie die Medicin gross gemacht hat.

Für die Pathologie des Nervensystems hat in hervorragendem Maasse eine Errungenschaft der rein experimentellen physiologischen Forschung eine geradezu fundamentale Bedeutung gewonnen: das Gesetz von den Functionen der Rückenmarksnervenwurzeln.

Nicht nur ist es eine der Grundlagen geworden für die Physiologie des nervösen Centralorgans, nicht nur wurde mit ihm die Erkenntniss des Bewegungsmechanismus der höheren Thiere und des Menschen erschlossen, nicht nur baut sich auf ibm mit die Ergründung der anatomischen Structur des Rückenmarkes wie des Centralnervensystems überhaupt auf, - auch für die Klinik ist es durch die Früchte, die es trug, zu umfassender Bedeutung herangewachsen.

Man lösche dieses Gesetz mit allen den Errungenschaften, die es für die Physiologie, die normale und pathologische Anatomie und die Diagnostik der Nervenkrankheiten zeitigte, mit allen den Errungenschaften, die es zur stillschweigenden Voraussetzung haben, 
aus, - und man wird erstaunt sein, wie wenig von den Kenntnissen übrig bleibt, die wir heute über das Nervensystem besitzen!

Die Entdeckung dieses Gesetzes, welches bis jetzt den Namen des Engländers Bell stragen hat, war lange Zeit in Dunkel gehüllt, und man darf wohl sagen, dass dieses Dunkel auch heute noch nicht vollständig gelichtet ist.

In dem Bewusstsein der Bedeutung, welche diesem physiologischen Erfahrungssatze für die gesammte medicinische Wissenschaft innewohnt, haben namhafte Gelehrte verschiedener Nationen es unternommen, den Schleier zu lüften, der über die Geschichte der Entdeckung dieses Lehrsatzes ausgebreitet lag. Es galt, zu entscheiden, ob der Mann, dem zu Ehren das Gesetz benannt ist, in Wahrheit die Würdigung verdient, die ihm durch die Bezeichnung dieses Lehrsatzes mit seinem Namen gezollt wird.

Als Erster trat im Jahre 1866 Vulpian ${ }^{1}$ ) mit einer historischen Studie über die Entdeckung dieses Gesetzes auf den Plan; Siegmund Mayer ${ }^{2}$ ) lehnt sich in seiner diesbezüglichen Abhandlung in Hermann's Handbuch der Physiologie an diese Arbeit an.

Die Untersuchung Vulpian's ist jedoch, wie wir uns überzeugt haben, nicht frei von Unrichtigkeiten, die Darstellung nicht historisch getreu.

Im Jabre 1867 greift Claude Bernard ${ }^{3}$ ) die Entdeckungsgeschichte des Bell'schen Gesetzes auf. Stolz auf seinen grossen Landsmann Magendie, ruft er über die „grande découverte“, wie er die Entdeckung jenes Lehrsatzes nennt, aus: „Elle appartient à la France!" Und er stützt sich dabei auf Vulpian's obengenannte Abhandlung, wenn er sagt:

„M. Vulpian a parfaitement développé les arguments qui prouvent que la découverte des fonctions des nerfs rachidiens appartient à Magendie. J'ai lu ce qu'il a écrit à ce sujet avec une grande satisfaction dans l'intérêt de la vérité et pour la gloire de la physiologie française" (l. c. pag. 157).

Im Jahre 1868 publicirt Flint ${ }^{4}$ ) eine Arbeit, in der er Bell fast jedes Verdienst an der Entdeckung des nach ihm benannten Lehrsatzes streitig macht.

Ueber ein Decennium später veröffentlichte $\operatorname{Eckhard}^{5}$ ) im Jahre 1883 gelegentlich anderer historischer Studien einen Aufsatz über die Entdeckung des Bell'schen Gesetzes. Es sei hier schon gleich das vorweggenommen, dass wir die Mittheilungen 
Eckliard's, soweit sie sich auf den vorliegenden Gegenstand beziehen, im Grossen und Ganzen als zutreffend haben bestätigen können. Da aber Eckhard das Original der in Frage kommenden Bell'schen Arbeit nic. zur Hand war, so darf man wohl dies zur Entschuldigung anführen, warum er in seinem Aufsatz den Bellschen Untersuchungen eine unserer Einsicht nach nicht vollkommene Würdigung zu Theil werden lässt.

Wenn man ausser den drei ersten der hier genannten speciellen Untersuchungen über diese Frage alles das mit in Betracht zieht, was - auch noch in der allerneuesten Zeit! - in physiologischen Lehrbüchern und in wissenschaftlichen Abhandlungen, die in irgend einer Beziehung zu dem genannten Gesetze stehen, über die Entdeckungsfrage dieses Lehrsatzes an meist unrichtigen und sich widersprechenden Angaben niedergelegt ist, dann kann man sich der Einsicht nicht verschliessen, dass wir auch heute noch nicht diese Frage als gelöst ansehen dürfen.

Im Gegentheil, der Engländer nimmt noch immer die Entdeckung dieses Lehrsatzes für den Engländer Bell in Anspruch, und der Franzose erkennt sie dem Franzosen Magendie zu; so hat sich der Kampf um dieses Idealgut fast dramatisch entwickelt.

Der Deutsche hat das wenig beneidenswerthe Vorrecht, diesem Streite als Unbetheiligter gegenüber zu stehen. Wenn er aber dieses Gesetz als Bell'sches Gesetz bezeichnet, und wenn diese Bezeichnung sich allgemeiner Uebereinstimmung unter den Autoren erfreut, wie das aus der Literatur hervorgeht, dann hat das den Anschein, als ob er damit stillschweigend anerkenne, es sei Bell, dem vor Allem das Verdienst an dieser Entdeckung gebühre.

Bei dieser Lage der Dinge schien es gerechtfertigt, die Frage nach der Entdeckung des Gesetzes über die Functionen der Rückenmarksnervenwurzeln einer erneuten Prüfung zu unterziehen und zu versuchen, ob es auf Grund der überlieferten Quellenangaben möglich sei, gewissermaassen eine Entscheidung in dem Kampfe, der sich um jene Frage entsponnen hat, herbeizuführen. Aber das war nicht der einzige Zweck dieser Untersuchung. Es sollte sich nicht nur darum handeln, festzustellen, ob Bell, ob Magendie oder ob Beiden zusammen der Siegespreis in diesem Kampfe gebübrt, sondern es sollte zugleich auch versucht werden, den Werdegang zu zeichnen, den die Physiologie genommen hat, um sich zur Erkenntniss jener fundamentalen Thatsache durchzuringen. Wir werden auf diese Weise 
einen Einblick gewinnen in den Zustand, in dem sich die Physiologie mit dem aufgehenden 19. Jahrhundert in Bezug auf diese Fragen aus der Nervenlehre befand. Und wenn wir dann jenes Bild mit demjenigen vergleichen, de.. die Physiologie an der Schwelle des neuen Jahrhunderts in eben diesen Gebieten uns exöffnet, dann werden wir unschwer abwägen können, was diese hundert Jahre uns gebracht, was sie auf jenem immerhin eng begrenzten Felde an Fortschritt geleistet und was wir ihnen da zu danken haben.

Wo und wann immer eine grosse Entdeckung gemacht wurde, trat sie nie - man könnte sagen: gleich einer Pallas Athene vollendet in die Welt und stand einsam und fern ab von den Erkenntnissen, zu denen der Menschengeist bis dahin sich emporgerungen hatte, sondern noch immer war es möglich, Stufen zu verfolgen, die zu ihrer Höhe hinaufführten.

Auch der Erkenntniss jenes Fundamentalgesetzes der Physiologie gingen zahlreiche Etappen voran. Wie eine Ahnung durchwehte es von jeher die Naturwissenschaft, dass den peripheren Nerven eine verschiedene Function zukomme, ein Vorgefühl, - man würde nicht mit Unrecht sagen dürfen, es sei, wie ein Pathengeschenk, dieser Wissenschaft in die Wiege gelegt worden.

Schon im Alterthume hatte man auf Grund der klinischen Erfahrung des getrennten Vorkommens sensibler und motorischer Lähmungen die Eintheilung der Nerven in Empfindungs- und Bewegungsnerven deducirt.

$\mathrm{Zu}$ den frühesten geschichtlichen Ueberlieferungen über diesen Gegenstand gehören die Angaben des $\mathrm{Er}$ a s is tra t u s ${ }^{2}$ ) (280 a. Chr. n.) und des Rufus aus Ephesus ${ }^{6}$ ) (100 p. Chr. n.), von denen der Erstere lehrte, dass die eine Nervenart von den Hirnhäuten, die andere von dem grossen und kleinen Gehirne entspränge.

Galen $\left.{ }^{7}\right)(130-200$ p. Chr. n.) näherte sich mit seinen Anschaungen schon etwas mehr der Wahrheit. Er liess die sensiblen und motorischen Nerven des Körpers beide vom nervösen Centralorgan selbst und insonderheit auch vom Rückenmark ausgehen. Ja, er verlieh dieser Auffassung bereits dadurch besonderen Nachdruck, dass er sie für therapeutische Eingriffe nutzbar machte.

Die Verschiedenheit der Function der vorderen und hinteren Rückenmarksnervenwurzeln aber ahnte Ga l en nicht im Entferntesten; seine Ausführungen erschöpften sich lediglich in der allgemeinen An- 
nahme, dass das Rückenmark besondere Nerven von sensiblem und besonders von motorischem Charakter entsende.

Diese Lehre Galen's in ihrer ganzen Unfertigkeit beherrschte die medicinische Wisse: schaft weit länger denn ein und ein halbes Jahrtausend.

Keiner der später lebenden Anatomen und Kliniker bis zum Beginne des 19. Jahrhunderts fügte der Lehre G al e n's ein wesentlich Neues hinzu, keiner that auch nur einen Schehritt voran.

Man begnügte sich mit geistvollen Speculationen, man knüpfte an die Erscheinungen, welche Nervenkranke boten, scharfsinnige Deductionen, ja man wollte aus der anatomischen Structur die Function der nervösen Organe ableiten, kurz, man theoretisirte da, wo man hätte experimentiren sollen. Fast nirgends tritt das Fiasco, das die Medicin in Bezug auf die Lösung physiologischer Fragen gemacht hat und machen musste, wenn sie sich von der strengen experimentellen Methode fernhielt, deutlicher zu Tage als in der Geschichte der Entdeckung der Functionen der Rückenmarksnervenwurzeln.

Auf welchen Abwegen sich die Wissenschaft in Bezug auf die Erkenntniss der Functionen der nervösen Organe selbst noch zu Beginn des 19. Jahrhunderts befand, geht aus Lamarck's berühmt gewordenen Schriften hervor.

Nach Lamarck ${ }^{8}$ ) war die Medulla oblongata gewissermaassen das Urhirn, aus dem nach der einen Seite Cerebrum und Cerebellum nebst den Nerven für die Sinnesorgane, nach der anderen Seite aber das Rückenmark sich entwickeln.

Die Functionen, welche den so gebildeten Centraltheilen innewohnen sollten, schildert Lamarck (l. c. p. 198) mit folgenden Worten:

„D'une part, le cerveau et ses hémisphères étant employés aux actes du sentiment et à ceux de l'intelligence, tandisque la moelle épinière ne sert qu'à l'excitation des mouvements musculaires et à l'exécution des fonctions organiques; et de l'autre part, l'emploi ou l'exercice des organes, fortement soutenu, les développant d'une manière éminente; il doit résulter que, dans l'homme qui excerce continuellement ses sens et son intelligence, le cerveau et ses hémisphères sont dans le cas de s'agrandir considérablement, tandisque la moelle épinière, en général foiblement exercée ne peut acquérir qu'une grosseur médiocre."

So seltsam diese Anschauungen L a m a rek's aus dem Jahre 1809 
uns auch heute anmuthen mögen, so sehr sie auch von dem wahren Sachverhalt der Dinge noch entfernt sind, - einen kleinen Fortschritt im Vergleich zu den Lehren Galen's, die auch damals noch immer lebendig waren, muss man anerkennen. Und dieser Fortschritt beruht darauf, dass Lamarck das Postulat in den Vordergrund der Betrachtung rückte, für die Empfindungs- und die Bewegungsnerven seien getrennte Ausgangspunkte aus dem Centralorgan anzunehmen; in der Localisation, welche er diesen Ausgangspunkten auf Grund seiner theoretischen Erwägungen gab, aber irrte er; seine Speculationen waren geistvoll, aber sie waren falsch.

Neben diesen Lehren Lam arek's erfreuten sich in jener Zeit auch noch ältere Ideen, die von dem Anatomen Willi is ${ }^{9}$ ) (1664) ausgingen, Ideen über die Anatomie und die daraus abgeleitete Physiologie der nervösen Centralorgane, einer unzweifelhaften Anerkennung. Zwischen den Anschauungen Lamarck's und denjenigen von Willis lässt sich eine gewisse Beziehung auffinden. Willis befasst sich, obschon in etwas anderer Weise wie Lamarck, mit: der Entwicklung des nervösen Centralorgans, wenn er schreibt (l. c. p. 63):

"Hie autem primo intuitu haec tria occurrunt, nempe Cerebrum, Medulla oblongata et Cerebellum: E quibus videtur quod Medulla oblongata sit Caudex communis, cui Cerebrum et Cerebellum velut Tubera adnascuntur. Quare nonnulli contendunt funen medullarem esse partem principem, Cerebrum autem et Cerebellum, appendices ejus: Attamen rem secus habere, hinc constat, quoniam haec corpora, in spirituum animalium tum generatione tum dispensatione, prioris et nobilioris sunt usus quam Medulla oblongata; ita nimirum, ut si spirituum effluxus e Cerebro aut Cerebello praecludatur, systema nervosum illico eclipsin patiatur; interim si hoc primario laboret Cerebrum aut Cerebellum haud necessario ejus noxam luunt."

Das Gehirn (Cerebrum) ist nun der Sitz der psychischen Eigenschaften des Menschen, so lehrt Will is weiter: "motuum et conceptuum omnium origo et fons est." (1. c. p. 64.) Es ist das Organ der bewussten Empfindungen und Bewegungen.

"Caeterea huius animae facultates," schreibt Willis an einer anderen Stelle (1. c. p. 64), „uti sensus et motus, item passiones et instinctus mere naturales elicet a Cerebro quod antenus dependent, tamen proprio in Medulla oblongata et Cerebello aut perficiuntur aut ab is procedunt." 
Im Gegensatz zum Cerebrum vermittelt das Cerebellum in erster Linie alle unbewussten Vorgänge des Körpers und dient so auch vornehmlich den "vitalen" Functionen (cf. 1. c. p. 104).

Durch die periphı...en Nerven, welche nun entweder mit dem Cerebrum oder dem Cerebellum in Verbindung stehen, wird der Einfluss dieser beiden Organe auf den übrigen Körper vermittelt.

Solcher Art waren damals die anatomischen Anschauungen über das Nervensystem; sie bildeten mit den mehr psychologisehen als physiologischen Betrachtungen, die sich an sie anschlossen, und die sich in den angegebenen Citaten von Lamarck und Willis widerspiegeln, gewissermaassen das Milieu, aus dem die Erkenntniss der Function der Rückenmarksnervenwurzeln im Beginne des 19. Jahrhunderts heraustrat.

Der Erste, welcher mit aller Bestimmtheit für die beiden Rückenmarksnervenwurzeln verschiedene Functionen postulirte, war im Jahre $1809 \mathrm{~W}$ alke ${ }^{10}$ ) in England, der die vorderen Wurzeln für sensorisch, die hinteren aber für motorisch erklärte.

W alker gehörte auch noch zu den Gelehrten, die ibrem Scharfsinn und ihrem Witze mehr zutrauten als der schlichten Beobachtung beim physiologischen Experimente. Er überlegte etwa folgendermaassen: Die beiden wichtigsten Functionen des Nervensystems sind Empfindung und Bewegung. Die Empfindung geht der Bewegung voraus. Das Gesicht, der Träger der wichtigsten Sinnesorgane, liegt dem Cerebrum am nächsten. Demnach muss dieses das Organ der Empfindung sein. Per exclusionem schliesst Walker auf die motorische Function des Cerebellums, zumal dieses ja auch eine dorsale, dem Gesichte entgegengesetzte Lage inne hat. Das Cerebrum steht durch die Pyramiden mit den Vordersträngen und den vorderen Wurzeln des Rückenmarks, das Cerebellum durch die corpora restiformia mit den Hintersträngen und den hinteren Rückenmarkswurzeln in Verbindung. Aus der Function der dominirenden Centraltheile: Cerebrum und Cerebellum, leitet sich die Function der von ihnen abhängigen Nervengebiete ab.

Diese Anschauungen hat W a lker, wie Eckhard (l. c.) treffend nachweist, niemals aufgegeben, auch nicht zu der Zeit, als das Experiment bereits $\mathrm{zu}$ seinen Ungunsten entschieden hatte.

Der erste bedeutsame Fortschritt, den die Physiologie seit Galen in der Erkenntniss der Functionen der Rückenmarksnervenwurzeln $\mathrm{zu}$-verzeichnen hat, wurde im Jahre 1811 durch die ex- 
perimentellen Untersuchungen von Charles Bell ${ }^{11}$ ) gemacht. Bell publicirte in diesem Jahre eine Schrift: "Idea of a new anatomy of the brain, submitted for the observations of his friends." (Siehe Anl.erkung Nr. 1.) In mehrfacher Beziehung so darf man wohl sagen - ist dieses Buch berühmt geworden; in ihm waren mit die ersten Arbeiten niedergelegt, durch die die experimentelle, vivisectorische Forschungsmethode mit Verständn iss in die Nervenphysiologie eingeführt ward: es musste ferner jede Untersuchung, welche sich späterhin mit der Frage nach der Entdeckung des sog. Bell'schen Gesetzes befasste, an jener Broschüre innigen Antheil nehmen; aber abgesehen davon haben zwei gewissermaassen negative Eigenschaften jenes Buch berühmt gemacht: sein spärliches Auftreten in den Bibliotheken und dann der Umstand er würde einen Vergleich dieses Buches mit Klopstock's "Messiade" rechtfertigen -, dass von jeher viel über diese Schrift geschrieben worden ist, ohne dass man sich dabei der Mühe ihrer Lectüre unterzogen hätte.

Die Heidelberger Universitäts-Bibliothek hat eine sehr sorgfältige Abschrift von dem einzigen Druckexemplar, das uns von der Bell'schen Arbeit bekannt ist, und das sich im Britischen Museum in London befindet, anfertigen lassen. Diese Abschrift stand uns zur Verfügung.

Den experimentellen Untersuchungen, über die Bell in seiner Schrift aus dem Jahre 1811 berichtet, lagen theoretische Erwägungen über die aus der Anatomie abgeleitete Pbysiologie des nervösen Centralorgans zu Grundé, die sehr viel Aehnlichkeit besitzen mit. den Lehren von Willis und Lamarck, deren wir oben eingehend gedacht haben.

Nach Bell verkörpern Cerebrum und Cerebellum in sich zwei grosse Abschnitte des Nervensystems, unter die sich der Rest der Hirn- und Marksubstanz unterordnet. Cerebrum und Cerebellum sind sowohl in ihrem Bau, als auch in ihren Verrichtungen verschieden; und demgemäss erscheinen die peripheren Nerven nicht mehr als Fäden, denen mannigfaltige Kräfte innewohnen, sondern sie sind Bündel verschiedener Nervenarten, deren Fasern zwar äusserlich mit einander verbunden, ihrer Function nach aber verschiedenartig sind. Und diese primitiven Nervenfäden, welche gemeinsam den Stamm des peripheren Nerven ausmachen, zerfallen in drei Kate- 
gorien; nämlich in 1 . sensible, 2. motorische und 3. vitale Nervenfasern.

Diese drei verschiedenen Arten von Nervenfasern treten aber aus dem Centralorgan nur an $\mathrm{zwei}$ Orten aus, und zwar dient ihnen entweder der vom Cerebrum oder der vom Cerebellum beherrsehte Abschnitt des Centralorganes als Ursprungsstätte.

Was insonderheit das Rückenmark angeht, so gehört der ventrale Markabschnitt dem Cerebrum zu, der dorsale dem Cerebellum, da sich in den ersteren die Crura cerebri, in den letzteren die Kleinhirnschenkel verfolgen lassen. Bell vermuthete auf Grund dieser Deductionen, dass es möglich sei, auf das Kleinhirn mittelst der hinteren und auf das Grosshirn mittelst der vorderen Markbündel einzuwirken; einige hierüber angestellte Experimente waren, wie er schreibt, für diese Ansicht günstig, wenn auch nicht streng beweisend.

Die weitere Untersuchung macht uns die genaue Bekanntschaft mit der Schrift Bell's aus dem Jahre 1811 unerlässlich.

Bell schreibt*): "I found, that injury done to the anterior portion of the spinal marrow convulsed the animal more certainly, than injury done to the posterior portion; but I found it difficult, to make the experiment without injuring both portions (siehe Anmerkung Nr. 2).

Next considering that the spinal nerves have a double root, and being of opinion, that the properties of the nerves are derived from their connections with the parts of the brain, I thought that I had an opportunity of putting ny opinion to the test of experiment, and of proving at the same time that nerves of different endowments were in the same cord, and held together by the same sheath.

On laying bare the roots of the spinal nerves, I found that I could $\mathrm{cut}$ across the posterior fasciculus of nerves, which took its origin from the posterior portion of the spinal marrow without convulsing the muscles of the back; but that on touching the anterior fasciculus with the point of the knife, the museles of the back were immediately convulsed.

Such were my reasons for concluding that the cerebrum and the cerebellum were parts distinct in function and that every nerve possessing a double function obtained that by having a double root.

*) 1. c. S. $21-23$. 
The spinal nerves being double, and having their roots in the spinal marrow, of which a portion comes from the cerebrum and a portion from the cerebellum, they convey the attributes of both grand divisions of the rain to every part."

Diese Angaben Bell's lassen sich etwa folgendermaassen resümiren :

„Auf Verletzung (injury done) der Vorderstränge des Rückenmarks erhält man ausgesprochenere Convulsionen des Thieres als auf diejenige der Hinterstränge; aber dieser Versuch ist unsicher.

Durchschneidung der hinteren Rückenmarksnervenwurzeln ruft keine Bewegung der Rückenmuskulatur hervor; Berührung der vorderen Nervenwurzeln löst Bewegungen dieser Muskeln aus.

Es besteht also ein functioneller Unterschied zwischen vorderen und hinteren Rückenmarksnervenwurzeln. Da die ersteren anatomisch mit dem Grosshirn, die letzteren mit dem Kleinhirn in Verbindung stehen, müssen die Vorderwurzeln dem Grosshirn, die Hinterwurzeln dem Kleinhirn dienstbar sein. Aus der Funetion der Grosshirns lässt sich diejenige der vorderen Wurzeln, aus der Funktion des Kleinhirns die Bedeutung der hinteren Wurzeln ableiten."

Es muthet uns seltsam an, wenn wir sehen, wie Bell, nachdem er glücklich einen physiologischen Versuch mit Erfolg ausgeführt hat, dessen Resultat unter eine vorgefasste Meinung knechtet und so zum Theil wieder zerstört, was er eben erst mühsam errichtet hat. Aus seinem Experiment schliesst er lediglich die allgemeine Thatsache: Die vorderen Wurzeln haben eine andere Function als die hinteren Wurzeln. Zur Präcisirung der Function der beiden Nervenwurzelarten aber verschmäht er das Experiment; er will sie aus der Function des Grosshirns und des Cerebellums, der beiden dominirenden Organe, herleiten. "The cerebrum," schreibt Bell*), "I consider as the grand organ, by which the mind is united to the body. Into it all the nerves from the external organs of the senses enter; and from it all the nerves, which are agents of the will pass out."

*) 1. c. S. 27 . 
Den Willensimpuls identificirt B ell mit dem motorischen Impulse ủberhaupt*); dieser Impuls geht vom Grosshirn aus, vom Organ des Bewusstseins; darauf weist die psychologische Beobachtung hin. Und so schliesst denn ; ell und stellt damit den ersten Theil des nach ihm benannten Fundamentalgesetzes auf: „From the erura cerebri or its prolongation in the anterior Fasciculi of the spinal marrow, go off the nerves of motion."**)

Somit hatte Bell der einen der drei Kategorien von Nerven, welche er, wie wir oben zeigten, annahm, ihr Ursprungsgebiet im nervösen Centralorgan angewiesen. Es erübrigte ihm jetzt noch die sensiblen und vitalen Nerven zu localisiren.

Die sensiblen Nerven theilt Bell in zwei Gruppen: er stellt die Seh-, Hör-, Riech- und Geschmacksnerven, als die Specialnerven der vier capitalen Sinnesorgane, den sensiblen Nerven des übrigen Körpers gegenüber.

Die erste Gruppe lässt vor ihrem Eintritt in das Gehirn Ganglienknoten (siehe Anmerkung Nr. 3) hervorgehen, die Bell als nothwendiges Attribut dieser Nerven durch die ganze Thierreihe hindurch ansieht. An der Basis des Gehirns sollen sich dann ferner an den Eintrittsstellen dieser Nerven circumseripte Partien befinden, welche als "internal organs of sense" bezeichnet werden. Diese „inneren" Sinnesorgane nehmen die Eindrücke ihrer correspondirenden äusseren Organe auf und bringen sie durch Erregung der anderen Hirnmasse dem Individuum zum Bewusstsein. Die andere Classe der sensiblen Nerven besitzt keine derartigen Ganglienknoten. Diese Nerven verlaufen vielmehr mit den motorischen Nerven zusammen und müssen nach Analogie der sensiblen Hirnnerven in die dem Cerebrum zugehörigen Theile der Medulla oblongata und des Rückenmarkes einmünden. Das betont Bell ausdrücklich, wenn er lehrt $\left.{ }^{* *}\right)$ : „With these nerves of motion, which are passing outward, there are nerves going inwards; nerves from the surfaces of the body; nerves of touch and nerves of peculiar sensibility, having their seat in the body or viscera."

Das unterscheidende Merkmal zwischen den motorischen und

*) Die Reflexbewegungen lässt Bell ganz ausser Acht, obschon diese Phänomene seit dem 17. Jahrhundert bekannt und oft beschrieben waren.

**) 1. c. S. 29 (cf. ferner S. 35 Zeile 20).

***) 1. c. S. 29. Dieser Satz schliesst sich im Texte unmittelbar an das. letzte Citat: „From the crura cerebri etc." an. 
den mit ihnen gemeinsam verlaufenden sensorischen Nerven ist daher nicht so sehr die verschiedene Ursprungsstätte im Centralorgan, sondern, wie Bell ausführt, der entgegengesetzte Verlauf der Fluida beider Nervenar .ən.

Mithin ist nach Bell das, was er die Cerebralregion des Centralnervensystems nennt, und worunter wir Cerebrum und die vorderen Medulla oblongata- und Rückenmarksstränge zu verstehen haben, das Organ, welches die sensiblen Nerven des Körpers aufnimmt, und das den motorischen als Ursprungsstätte dient. Es bleibt Bell nunmehr nur noch übrig, seine vitalen Nerven einzurangiren.

"The cerebellum," so lehrt er*), "when compared with the cerebrum is simple in its form. It has no internal tubercles or masses of cineritious matter in it. The medullary matter comes down from the cineritious cortex and formes the crus; and the crus runs into union with the same process from the cerebrum; and they together form the medulla spinalis and are continued down into the spinal marrow; and these crura or processes afford double origin to the double nerves of the spine. The nerves proceeding from the crus cerebelli go every where (in seeming union with those from the crus cerebri); they unite the body together, and controul the actions of the bodily frame; and especially govern the operation of the viscera necessary to the continuance of life."

An einer anderen Stelle heisst es**): "The secret operations of the bodily frame and the connections which unite the parts of the body into a system, are through the cerebellum and nerves proceeding from it."

Und endlich sei hier noch eine dritte. Stelle***) aus Bell's Arbeit citirt, um zu zeigen, dass Bel] die hinteren Rückenmarksnervenwurzeln als vitale Nerven erachtete: "The $8^{\text {th }}$ nerve is from the portion of the medulla oblongata (the medulla oblongata is only the commencement of the spinal marrow), which belongs to the cerebellum, the 9 th nerve comes from the portion, which belongs to the cerebrum. The first is a nerve of the class, called vital nerves, controuling secretly the operation of the body; the last is the motor nerve of the tongue, and is an instrument of volition."

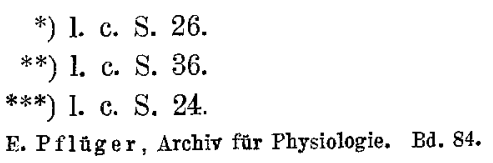


Doch hiermit wollen wir die Beweisaufnahme schliessen, um zum Urtheil zu kommen.

Die vorderen Rückenmarksnervenwurzeln sind gemischt, motorisch und sensorisch, den hinteren aber stehen allgemeine vitale Functionen zu.

So würde das Bell'sche Gesetz aus dem Jahre 1811 lauten.

Wie uns der Titel der Bell'schen Schrift belehrt, war diese nur für den Freundeskreis des Verfassers bestimmt und nicht im Buchhandel erschienen. So erklärt es sich, dass sie selbst unter den Fachgenossen Bell's ziemlich unbekannt blieb, und dass während des folgenden Jahrzehntes ohne Kenntniss der Bell'schen Erfahrungen über die Function der Spinalnerven von anderen Gelehrten experimentirt wurde.

Im Jahre 1819 stellten $\mathrm{Burdach}$ und $\mathrm{Baer}{ }^{12}$ ) resultatlose Versuche in dieser Beziehung an Fröschen an. Sie durchschnitten diesen Thieren auf der einen Seite die hinteren, auf der anderen die vorderen Wurzeln, und sahen, dass in beiden Fällen die Extremitäten welk und unempfindlich waren. .

Im Jahre 1821 und 1822 reproducirte J. Shaw ${ }^{13}$ ), ein Schüler Bell's, die allgemeine Erfahrung seines Lehrers, dass die hinteren Wurzeln functioneli verschieden seien von den vorderen Wurzeln.

Erst mit den im Jahre 1822 publicirten Untersuchungen Magendie's trat diese ganze Frage in eine neue Phase ein.

Magendie war die Arbeit Bell's gleichfalls unbekannt. Das geht aus seinem Briefwechsel mit Shaw zweifellos hervor. Kurz nachdem Magendie seine erste Mittheilung über die Physiologie der Rückenmarksnervenwurzeln publicirt hatte, theilt ihm Shaw mit, dass Bell bereits 13 Jahre früher zu den gleichen Beobachtungen gelangt sei (siehe Anm. Nr. 4). Magendie lässt sich darauf von Shaw die betreffende Schrift Bell's senden, und erwidert dann, wie folgt:

„On voit par cette citation d'un ouvrage que je ne pouvois connaître, puisqu'il n'a point été publié, que M. Bell, conduit par ses ingenieuses idées sur le système nerveux, a été bien près de découvrir les fonctions des racines spinales; toutefois le fait, que les antérieures sont destinées au mouvement, tandisque les postérieures appartiennent plus particulièrement au sentiment, paraît lui avoir 
échappé: e'est done à avoir établi ce fait d'une manière positive que je dois borner mes prétentions"*).

Doch wenden wir uns nach dieser Abschweifung den eigentlichen Untersuchungen Mage $\lrcorner$ die's zu. ${ }^{14}$ )

Schon lange hatte Magendie die Absicht, so berichtet er in seiner ersten Arbeit aus dem Jahre 1822, auf vivisectorischem Wege die Function der Rückenmarksnervenwurzeln zu studiren; doch dieser Plan sollte erst damals, als man ihm zufällig acht junge Hunde in's Laboratorium brachte, zur Ausführung kommen. Er öffnete einem dieser Thiere den Wirbelcanal, durchtrennte die Dura mater und durchschnitt auf einer Seite die hinteren Wurzeln. Anfangs sehien das Thier an der betreffenden Extremität, die völlig unempfindlich war, auch gelähmt zu sein. "Mais bientôt à ma grande surprise," so berichtet er, „je le vis se mouvoir d'une manière très apparente, bien que la sensibilité y fût toujours tout à fait éteinte."**)

Sodann operirte er ein anderes Thier an den vorderen Wurzeln einer Seite, ohne die hinteren dabei zu lädiren. Die betreffende Extremität war vollständig unbeweglich und wurde bei der Locomotion schlaff nachgeschleift, indessen sie ihre Sensibilität vollkommen bewahrt hatte.

Endlich durchschnitt er die vorderen und hinteren Wurzeln einer Seite; der Erfolg war der erwartete: die Extremität war unbeweglich und gefühllos.

Den Schluss, den er aus den mitgetheilten Versuchen zieht, theilt er in folgenden Worten mit***):

"Il me suffit de pouvoir avancer aujourd'hui comme positif, que les racines antérieures et les postérieures des nerfs qui naissent à la moelle épinière, ont des fonctions différentes, que les postérieures paraissent plus particulièrement destinées à la sensibilité, tandis que les antérieures semblent plus spécialement liées avec le mouvement."

Wie wir sahen, hatte Bell die These aufgestellt, dass die vorderen Wurzeln motorisch und sensibel wären, dass den hinteren allgemeine vitale Functionen zuständen. Die Mittheilung Magendie's von der motorischen Function der vorderen Wurzel enthielt also keine neue Thatsache. Wohl aber gebührt Magendie das Ver-

*) Journal de Physiologie expér. et pathol. 1822, S. 371. Hier ist der Briefwechsel mit Shaw von Magendie mitgetheilt.

**) 1. c. 1882 S. 277 .

***) 1. c. 1822 S. 279. 
dienst, hier dargethan zu haben, dass die hinteren Wurzeln sensibler Natur sind.

Doch Alles in Allem genommen: Magendie zweifelte damals bereits, dass man die Berechtigung habe, die Functionen beider Wurzelgruppen vollkommen, etwa in einer absoluten Weise, zu trennen. Diesen Zweifel sprach Magendie noch deutlicher aus in der zweiten Abhandlung über den gleichen Gegenstand, die Ende des Jahres 1822 erschien.

In diesem Aufsatz theilt Magendie zunächst Versuche über die Wirkung der nux vomica bei Thieren mit durehschnittenen vorderen Wurzeln für eine Extremität mit. Der Tetanus bleibt an der operirten Seite aus.

Alsdann sucht Magendie folgende Fragen durch das Experiment zu lösen :

1. En irritant directement les nerfs du sentiment, ou les racines spinales postérieures, produirait-on des contractions?

2. Une irritation directe des nerfs du mouvement exciteraitelle de la douleur?*)

Die Versuchsanordnung war eine doppelte: entweder wurden die mit dem Mark zusammenhängenden Wurzeln mechanisch oder elektrisch gereizt, oder es wurden die Wurzeln erst durehschnitten, und es fand nunmehr eine mechanische oder elektrische Reizung der peripheren Stüimpfe statt.

Die Versuchsergebnisse waren folgende:

Mechanische und elektrische Reizung der mit dem Rückenmark zusammenhängenden Nervenwurzeln liess in ihrem Effect keine scharfe Trennung der Function beider Wurzelarten zu.

Das gleiche Resultat hatte die elektrische (galvanische) Reizung der peripheren Stümpfe der durchschnittenen Wurzeln.

Die mechanische Reizung der peripheren Wurzelstümpfe aber hatte folgendes Ergebniss, das wir mit Magendie's eigenen Worten wiedergeben wollen:

„Je dois dire qu'excepté sur deux animaux où j'ai vu des contractions, quand je pinçais ou tiraillais les faisceaux antérieurs et posterieurs, dans tous les autres cas je n'ai observé aucun effet

*) 1. c. 1822 S. 367 . 
Eine hist. Studie üb. d. Entdeckung d. Magendie-Bell'schen Lehrsatzes. 291

sensible de l'irritation des racines antérieures ou postérieures ainsi séparées de la moelle."*)

Bei diesem Passus können wir allerdings Mag endie den Vorwurf der Unklarheit $n_{\curvearrowright}$ ht ganz ersparen, denn der Ausdruck „effet sensible", wie er hier gebraucht wird, kann in doppelter Weise verstanden werden.

1. Effet sensible = effet perceptible à l'observateur; d. h. Magendie hat keine Muskelbewegungen oder sonst welche Reactionen auf die Nervenreizung hin gesehen.

2. Effet sensible = effet sur le sensorium de l'animal; d. h. das Versuchsthier hatte den Reiz nicht empfunden.

Die zweite Deutung ist wohl die richtigere.

Wenn wir hier noch ein Mal Magendie's Versuche resumiren, so ergibt sich, dass Magendie bei mechanischer und galvanischer Reizung der mit dem Centralorgan verbundenen hinteren Wurzeln neben den Schmerzreactionen auch directe motorische Erfolge beobachtet haben wollte. Und zwar spricht er als solche motorische Erfolge die Bewegungen an, welche in den Muskelgruppen auftraten, die in dem Verbreitungsbezirk der gereizten sensiblen Nerven lagen. An die Möglichkeit der reflectorischen Natur dieser Bewegungen dachte Magendie nicht. Umgekebrt beobachtete Magendie nach mechanischer und galvanischer Reizung der Vorderw urzeln neben den motorischen Effecten Schmerzäusserungen.

Nach mechanischer Reizung der vorderen wie hinteren peripheren Wurzelstümpfe - es wurden bei diesen Versuehen stets beide Wurzeln auf ein Mal durchtrennt - sah Magendie, abgeseben von zwei Fällen, auf die er kein Gewicht legt, niemals Schmerzäusserungen bei den Thieren auftreten.

Bei galvanischer Reizung der peripheren Wurzelstümpfe beobachtete er auch nach Reizung der hinteren Wurzel motorische Reactionen.

Gerade diese letztere Angabe wurde späterhin immer wieder gegen die rein sensorische Natur der hinteren Wurzel in's Feld geführt, bis du Bois-Reymond die Vermuthung aussprach, dass diese Erscheinung nur dem Elektrotonus ihren Ursprung verdanken könnte, und bis Schiff diese Idee du Bois-Reymond's durch weitere Versuche zu einer gesicherten Thatsache erhob.

*) 1. c. 1822 S. 369 . 
Als Résumé seiner Versuche schreibt Magendie auch in dieser zweiten Abhandlung des Jahres 1822 ähnlich wie in der ersten Arbeit:

"Ces faits sont c.unc confirmatifs de ceux que j’ai annoncés; seulement ils semblent établir que le sentiment n'est pas exclusivement dans les racines postérieures, non plus que le mouvement dans les antérieures." *)

Aus den Mittheilungen Magendie's, die wir im Vorstehenden wiedergegebén haben, erhellt, dass $M$ a g e $n$ di e, höchstwahrscheinlich vollkommen unabhängig von Bell, im Jahre 1822 auf experimentellem Wege zur Erkenntniss der Thatsache gelangte, dass die vorderen Wurzeln mit der Motilität, die hinteren mit der Sensibilität in Beziehung ständen. Aber Magendie sprach diese Erfahrung nicht schlechthin aus, sondern er liess ihr eine gewisse Einschränkung widerfahren. Der Lehrsatz, den Magendie im Jahre 1822 aufstellte, würde etwa folgendermaassen lauten:

Die vorderen Rückenmarksnervenwurzeln haben vorwiegend motorische, die hinteren vorwiegend sensorische Functionen.

Magendie hatte also durch seine Versuche in jenem denkwürdigen Jahre 1822 die verschiedene Function der vorderen und hinteren Wurzeln über jeden Zweifel gesichert; aber er hatte gleichzeitig die Frage den Physiologen zur Entscheidung vorgelegt, ob die Verschiedenheit der Function der beiden Wurzeln eine vollkommene wäre, oder ob die Verhältnisse so lägen, wie er sie einschränkend dargestellt hatte.

Schon im December des Jahres 1822 trat Fodéra ${ }^{15}$ ) mit Experimenten hervor, die ihn Mag endi e's Angaben bestätigen liessen. Aber Fodéra sowohl wie Béclard ${ }^{16}$ ) im Jahre 1823 formulirten das Gesetz, obschon ohne genügenden Grund präciser, sie liessen es ohne Finschränkung gelten, und es war besonders Béclard, der ihm als Erster die Fassung gab, in welcher es heute noch gewöhnlich vorgetragen wird, wenn er schrieb**): „Les expériences de Mr. Bell, celles de Mr. Magendie et les miennes propres ont clairement démontré que la racine postérieure des nerfs spinaux est sensoriale et la racine antérieure motrice."

*) 1. c. 1822 S. 368 .

**) 1. c. S. 668 . 
Eine hist. Studie üb. d. Entdeckung d. Magendie-Bell'schen Lehrsatzes, 293

Im Jahre 1823 publicirte ferner Belling eri ${ }^{17}$ ) Versuche über die Function der Rückenmarksnervenwurzeln; es sollten beim Frosch die hinteren Wurzeln dem Gefühl und den Extensionsbewegungen, die vorderen Wurzeln d. Flexionsbewegungen dienen. H. M ay ow ${ }^{18}$ ) bekennt sich im gleichen Jahre (1823) auf Grund eigener Versuche Magendie's Ansicht zu.

Wir können über die Arbeiten von Amussat ${ }^{19}$ ) (18:24), Schoeps ${ }^{20}$ ) (1827) und Rolando ${ }^{21}$ ) (1828) füglich hinweggehen, da sie entweder zu dem Gegenstande nichts Neues brachten, oder da das Neue, das sie enthielten, obendrein unzutreffend war. Erst Backer ${ }^{22}$ ) trat 1828 wieder mit Ernst an die Prüfung des Problems heran, das Mage $\mathrm{ndi}$ e seiner Zeit den Physiologen zur Entscheidung vorgelegt hatte. Backer entschied sich gegen Magendie. Seine Versuche zeigten bei Durchschneidung der hinteren Wurzel lediglich Schmerzreactionen, während eine nachträgliche Reizung der vorderen Wurzel - also nach vorheriger Section der zugehörigen Hinterwurzel! - ausschliesslich motorische Reactionen auslöste. Man sieht: zwar sind die Versuchsergebnisse Backer's vollkommen eindeutig und bei der gewählten Versuchsanordnung auch unzweifelhaft richtig, aber diese Experimente konnten trotzdem nieht den wahren Sachverhalt aufdecken, da bei ihnen die rückläufige Sensibilität eben einfach ausgeschaltet wurde. Die definitive Klarlegung dieser Fragen, soweit sie die rückläufige Sensibilität betreffen, war dem Scharfsinne Magendie's selbst vorbehalten.

Im Jahre 1831 trat J. Mülle ${ }^{23}$ ) mit seinen Untersuchungen über die Function der Rückenmarksnervenwurzeln auf den Plan.

Die Versuche Müller's waren doppelter Art. Genau wie Magendie durchschnitt er entweder die Wurzeln isolirt und beobachtete den Erfolg dieser Operation, oder er reizte die mit dem Rückenmark in Verbindung stehenden Wurzeln oder die von ihm getrenntel an ihren peripheren Stümpfen.

Der Durchschneidungsversuch, der von Müller zum ersten Male in jener so überaus markanten Form am Frosch, bei der ein solches Thier auf der einen Seite nur Sensibilität und auf der anderen nur Motilität besitzt, ausgeführt wurde, sprach für eine strenge Unterscheidung der Function der beiden Wurzelarten. Die Reizungsversuche hingegen mussten auch J. Müller noch Zweifel iuber eine derartig stringente Fassung des Gesetzes bestehen lassen, denn die Reizung der mit dem Rückenmark in Verbindung stehenden Wurzeln ergab ihm speciell für 
die vorderen Wurzeln keine so sicheren Resultate, dass er auf Grund deren die vollkommene Unempfindlichkeit der vorderen Wurzel auszusprechen gewagt hätte. Wohl aber beobachtete Müller, dass mechanische oder elekt sche Erregung der hinteren Wurzel, gleichviel, ob sie mit dem Marke noch zusammenhing, oder ob nach ihrer Abtrennung ihr centraler Stumpf gereizt wurde, niemals motorische Reactionen auslöste, die nicht als Schmerzäusserungen gedeutet werden mussten; die Reizung des peripheren Stumpfes hatte überhaupt keinen sichtbaren Erfolg*).

Was also die Schlussfolgerungen aus den Mülle r'schen Versuchen über die Function der hinteren Wurzeln anlangte, so deckten sie sich mit den diesbezüglichen Angaben Backer's; diese beiden Autoren standen im Gegensatz zu Magendie, der die hintere Wurzel nicht ausschliesslich sensorisch sein liess.

Hinsichtlich der Function der vorderen Wurzel stand Müller mit seinen Anschauungen, die er allerdings niemals scharf hervorgehoben hat, im Wesentlichen auf dem Boden der Lehre Magen die's aus dem Jahre 1822. J. Müller maass offenbar, wie man aus seinen Arbeiten zu folgern berechtigt ist, der Frage nach der ausschliesslich motorischen Functionen der vorderen Wurzel keine so hohe Bedeutung zu, als ihr in Wahrheit innewohnt. Sonst hätte er präciser dazu Stellung nehmen müssen. Backer hingegen hatte die vordere Wurzel als rein motoriseh angesprochen, wie wir sahen. Er befand sich in diesem Punkte mit Magendie und, wie gesagt, wohl auch mit Müller im Widerspruch.

In dem Streite, ob die Function der beiden Wurzelarten eine vollkommen verschiedene sei oder nicht, war bis zum Jahre 1831 noch keine Entscheidung herbeigeführt. Auch die späteren Arbeiten, welche bis zu Magendie's Mittheilung über die „Sensibilité récurrente" der vorderen Wurzel im Jahre 1839 veröffentlicht wurden, förderten die angeregten Fragen kaum. Es sind das die Untersuchungen von Seubert ${ }^{24}$ ) (1831), Tiedemann ${ }^{25}$ ) (1832), Stannius ${ }^{26}$ ) (1832), Retzius $\left.{ }^{27}\right)$ (1832), van Deen ${ }^{28}$ ) (1834) und Panizza ${ }^{29}$ ) (1834).

Dank der Unsicherheit, in der sich Magendie nach dem Jahre 1822 noch über die Resultate seiner Versuche befand, forschte

*) J. Müller hatte also bei galvanischer Reizung der Hinterwurzeln keine Wirkung des Elektrotonus auf die vordere Wurzel beobachtet. 
er weiter, hielt er nicht inne, zu experimentiren. Die Durchschneidungsversuche an den Rückenmarksnervenwurzeln waren ja wohl eindeutig, nicht so die Reizungsversuche, auf die Magendie scheinbar ein grössere. Gewicht legte. Und so arbeitete er fort; über ein und ein halbes Jahrzehnt hielt ihn dieses Problem gefangen, und erst im Jahre 1839 sah er vollkommen klar: er konnte jetzt mit der Lehre von der rückläufigen Sensibilität der vorderen Wurzeln vor die Oeffentlichkeit treten. (Siehe Anmerkung Nr. 5.)

Er that somit einen wesentlichen Schritt weiter voran in der Erforschung der Wahrheit. Die vordere Wurzel besitzt Sensibilität; aber sie birgt keine sensiblen Fasern im Sinne der hinteren Wurzeln selbst, sondern sie besitzt Sensibilität im Sinne peripherer Organe des Körpers, die sensibel innervirt werden. Auf diese Art waren die Beobachtungen über die Empfindlichkeit der vorderen Wurzel erklärt, und diese Empfindlichkeit war nochmals in unzweifelbafter Weise dargethan worden. Sensorische Fasern im Sinne von eigentlichen Wurzelfasern enthält die vordere Wurzel also nicht; und es ist bis auf den heutigen Tag auch keine Erfahrung bekannt geworden, aus der man folgern dürfte, dass die vordere Wurzel ausser den Fasern, welche die Sensibilité récurrente vermitteln, irgend welche centripetalleitenden Nervenfasern in sich schlösse.

Einer weiteren Forschung war es vorbehalten, zu zeigen, dass die in der vorderen Wurzel eingeschlossenen centrifugalleitenden Fasern nicht nur der Motilität dienstbar sind.

Dieses Problem hatte Magendie noch nicht aufgestellt, denn bei ibm handelte es sich immer nur um die zwei Kategorien, um Sensibilität oder Motilität.

Es ergab sich mit der Zeit aber eine Erweiterung der Magendieschen Fragestellung: nicht galt es mehr allein, zu entscheiden, ob die vordere Wurzel nicht auch noch Sensibilität neben ihrer motorischen Function besässe, was $\mathrm{Magendie}$ nunmehr klargelegt hatte, oder ob die hintere Wurzel nicht auch motorischen Charakter hätte neben ibrem sensorischen, sondern die Fragestellung lautete allgemein: Welchefunctionell verschiedenen Faserarten beherbergt überhaupt die eine und die andere Wurzel?

Wir haben bis zum Jahre 1839 in streng chronologischer Reihenfolge die Arbeiten angeführt und gewürdigt, welche bis dahin über die Functionen der Rückenmarksnervenwurzeln erschienen waren. Es 
liegt nicht in unserer Absicht, diese Aufzählung bis auf die Gegenwart fortzuführen, noch auch ist. es hier der Ort, diejenigen Untersuchungen zu behandeln, welche sich zwar mit der Physiologie der sensiblen und motorisel in Nerven überhaupt beschäftigen, aber nicht zum Gegenstande haben, zu präcisiren, was die in den Rückenmarkswurzeln eingeschlossenen Nervenfasern ihrer physiologischen Leistung nach sind. Wir lassen daher absichtlich ausser Acht die ganze Lehre von der sensorischen Ataxie, die Lehre vom reflectorischen Muskeltonus, die Lehre von der Erregbarkeit der vorderen Wurzeln nach Durchschneidung der hinteren, die Beobachtungen über Reflexe von Hinterwurzel zu Hinterwurzel und dergleichen Erfahrungen mehr, da sie alle streng genommen nichts mit dem Gesetze zu thun haben, das besagt, aus welchen functionell verschiedenen Einheiten sich die beiden Wurzelarten zusammensetzen.

Unter der grossen Zahl von physiologischen Untersuchungen, die bis auf den heutigen Tag nach dem Jahre 1839 über die Rückenmarksnervenwurzeln erschienen sind, baben nur wenige uns in der Erkenntniss dieses Gesetzes um ein Wesentliches gefördert. Auf diese wenigen Árbeiten müssen wir nunmehr eingehen; wir wollen sie behandeln, je nachdem sie sich mit der vorderen oder mit der hinteren Wurzel beschäftigen.

Den ersten grossen Fortschritt haben wir seit Bell's und Magendie's Untersuchungen auf diesem Gebiete Pflüger ${ }^{30}$ ) zu verdanken. Durch seine Arbeiten aus den Jahren 1855 und 1856 wurde mit einem Schlage für die Analyse der speciell in den vorderen Wurzeln eingeschlossenen, functionell verschiedenartigen Nervenfasern ein vollkommen neuer Gesichtspunkt gewonnen.

Pflüger zeigte damals den centrifugalen Einfluss, den die vordere Wurzel auf die Blutgefässe besitzt: Reizung der vorderen Wurzel ruft beim Frosch Contraction der Gefässe der Schwimmhaut hervor. Die vordere Wurzel beherbergt demnach vasomotorische Fasern*).

Eine abermalige Erweiterung erfuhren unsere Kenntnisse über die Function der vorderen Wurzeln dann späterhin durch die Arbeiten von Adamkiewicz ${ }^{31}$ ) und Vulpian ${ }^{32}$ ) aus dem Jahre 1878, in denen dargethan wurde, dass die vorderen Wurzeln Fasern

*) Nach I. Munk lässt sich dieser Versuch am einwandfreisten am curarisirten Frosche ausfübren. 
führen, welche in centrifugalem Sinne auf die $\mathrm{Sch}$ weisssecretion Einfluss haben. Faradisation der vorderen Wurzeln lässt in den ihnen zugehörigen Körpertheilen Schweisssecretion auftreten.

Es ist hier der Ort, ferner der nach der Angabe einiger Autoren in der vorderen Wurzel eingeschlossenen motorischen Fasern für gewisse, mit glatte $\mathrm{n}$ Muskeln versehene Organe: Harnblase, Samenleiter, Uterus, zu gedenken, wie an die in eben dieser Wurzel verlaufenden trophischen Fasern für die Gewebe und an die Hemmungsfasern für die Contraction der Gefässe, Vasodilatatoren, zu erinnern, die nach der Meinung einer Reihe von Physiologen ebenfalls in den vorderen Wurzeln ibren Verlauf haben*).

Alle diese Faserarten zusammen bilden nach dem heutigen Stande unserer Kenntnisse die vorderen Wurzeln. Sie besitzen ausschliesslich centrifugale Fasern; dem widersprechen auch die anatomischen Untersuchungen nicht; die centripetalen Fasern, welche als Träger der Sensibilité récurrente fungiren, sind im strengen Sinne des Wortes keine Wurzelfasern, wie wir gezeigt haben.

Wenden wir uns nunmehr zur Geschichte der Physiologie der hinteren Wurzeln nach dem Jahre 1839 !

Im Jahre 1856 beobachtete Brown-Séquard**) bei Säugethieren nach Durchschneidung hinterer Wurzeln Gefässerweiterung und Temperaturerhöhung an den von diesen Nerven innervirten Gliedmaassen; im Jahre 1876 wurde durch Stricker ${ }^{33}$ ) die Thatsache bekannt gegeben, dass man durch Reizung hinterer Wurzeln eine centrifugale, gefässerweiternde Wirkung beim Thiere erzielen könnte. Morat bestätigte diese Entdeckung.

Vierzehn Jahre später fand M. v. Lenhossék ${ }^{34}$ ) auf anatomischem Wege, dass die hintere Wurzel Fasern - und zwar im Sinne von Wurzelfasêrn - einschliesst, deren Ganglienzellen in den Vorderhörnern gelegen sind. Dieser Befund wurde späterhin von fast allen Autoren bestätigt; zugleich war er wohl dazu angethan, die Stricker'schen Erfahrungen unserem Verständniss näher zu bringen. Aber die vasodilatatorische Wirkung der hinteren Wurzel sollte nicht lange die einzige bekannte centrifugale Funetion dieser Wurzel bleiben.

*) Landois, Lehrb. der Physiologie. 1893, pag. 764 a. 765.

**) Gaz. méd. d. Paris 1856 no. 16, 17, 23. 
Im Jahre 1895 konnte nämlich Steinach ${ }^{35}$ ) zeigen, dass die hintere Wurzel beim Frosch die glatte Muskulatur des Darmtractus und der Blase, genau wie die vordere Wurzel die quergestreifte Skelettmuskulatur, mo risch innervirt. Stein ach ging bei diesen Versuchen von entwicklungsgeschichtlichen Betrachtungen aus.

$\mathrm{Ob}$ sich nun in jenen von Lenhossék entdeckten "durchziehenden" Fasern die centrifugalen Fasern der hinteren Wurzeln überhaupt erschöpfen, das ist eine Frage, die vorläufig noch ihrer Lösung harrt.

Jedenfalls aber dürfen wir heute das als eine wohl gesicherte Thatsache ansehen, dass die hintere Wurzel, neben ihren centripetalleitenden Fasern, Fasern besitzt von centrifugaler Natur, und dass diese in motorische Fasern für die glatte Muskulatur und in vasodilatatorische Fasern zerfallen. Wir können unsere heutigen Kenntnisse über die Function der hinteren Wurzel dahin zusammenfassen, dass wir sagen: Die hintere Wurzel besitzt an Wurzelfasern:

I. Centripetale Fasern (sensorische Fasern).

II. Centrifugale Fasern:

1. vasedilatatorisehe Fasern;

2. motorische Fasern für die glatte Muskulatur der Eingeweide beim Frosch.

Man sieht, dass das Gesetz über die Functionen der Rückenmarksnervenwurzeln, das Gesetz, welches die physiologische Natur der in diesen Wurzeln eingeschlossenen Fasern darthun soll, sich complicirter und in seiner vollkommenen Erkenntniss, von der wir auch heute noch nicht wagen dürfen zu behaupten, dass wir sie errungen hätten, unendlich viel schwieriger herausstellte, als es im Jahre 1811 Bell und im Jahre 1822 Magendie ahnten und ahnen konnten.

Pflüger, Brown-Séquard, Adamkiewicz, Vulpian, Stricker, Lenhossék und Steinach deckten Gesichtspunkte auf, unter denen die Physiologie der Rückenmarksnervenwurzeln behandelt werden musste, Gesichtspunkte, an die weder Bell noch Magendie, noch die grosse Zahl jener anderen Forscher, die bis zum Erscheinen jener ersten Arbeit Pflüger's im Jabre 1855 über die Functionen der beiden Wurzeln arbeiteten, gedacht haben.

Aber dennoch wird man andererseits nicht leugnen dürfen, dass der Grund zu unseren Kenntnissen, die wir heute über die Function 
der Rückenmarksnervenwurzeln besitzen, durch die Arbeiten Bell's und Magendie's gelegt wurde.

Bell sprach im Jahre 1811 sich dahin aus, dass die vorderen Rückenmarksnervenwur_əln motorisch und sensorisch, die hinteren aber von vitaler Function seien.

An diesem Satze war gewissermaassen eine vierfache Correctur anzubringen, erstlich dass die vorderen Wurzeln nicht sensoriseh in dem Sinne Bell's seien, zweitens dass die hinteren Wurzeln keine vitalen Nerven enthielten, drittens dass diese Wurzeln vielmehr sensorische Function hätten, und dass viertens vordere und hintere Wurzeln neben ihren motorischen und sensorischen Eigenschaften auch noch Fasern anderer Functionen beherbergten.

Wenn, wie oben gezeigt wurde, Magendie schon im Jahre 1822 auf Grund seiner diesbezüglichen Untersuchungen den Satz aufgestellt hat, dass die vorderen Wurzeln vorwiegend motorisch, die hinteren vorwiegend sensorisch sind, dann kommt diesem Satze in der einschränkenden Fassung auch heute noch vollkommene Gültigkeit zu; allerdings muss diese Einschränkung in wesentlich anderem Sinne gefasst werden, als er ihr von Magendie damals untergelegt wurde. Wir haben das im Verlauf unserer geschichtlichen Darstellung eingehend begründet.

Wenn wir nun hier am Schlusse unserer Untersuchung ein Urtheil fällen sollen, wem, ob Bell, ob Magendie das wesentliche Verdienst an unseren heutigen Kenntnissen über die Functionen der Rückenmarksnervenwurzeln zusteht, dann müssen wir anerkennen, dass Magendie ungleich das Grössere geleistet hat, dass er der Wahrheit am nächsten gekominen ist; aber wenn wir berücksichtigen, wie weit in den Tagen seiner Untersuchungen die ganze Nervenphysiologie bereits vorangeschritten war, im Vergleich zum Jahre 1811, dann dürfen wir Bell's Verdienst doch auch nicht ganz gering anschlagen. Und für die Wissenschaft ist es gleichgültig, ob Magendie um Bell's Versuche gewusst hat oder nicht; die motorische Function der vorderen Wurzel war 1811 von Bell zum ersten Male experimentell dargethan worden (siehe Anmerkung Nr. 6), nach Reizung der vorderen Wurzeln hatte Bell Muskelbewegungen auftreten sehen.

Aber das rechtfertigt nicht, das Gesetz über die Functionen der Rückenmarksnervenwurzeln als "Bell'sches Gesetz" schlechthin $\mathrm{zu}$ bezeichnen. Es ist eine langhin verzögerte Ehrenpflicht dem 
Franzosen Magendie gegenüber, der wir nachkommen, wenn wir fortan dieses Gesetz "Magendie-Bell'sches Gesetz" nennen. (Siehe Anmerkung Nr. 7.)

\section{A n merk u ge en.}

Nr. 1. Eine Jahreszahl ist auf der Druckschrift, die sich im britischen Museum befindet, nicht angegeben. Man glaubte lange Zeit, dass das Buch 1809 erschienen sei. Bell gibt jedoch selbst in seiner Schrift: The nervous system of the human body etc. London 1830, an, dass das Jahr der Drucklegung der Abhandlung: Idea of a new etc. 1811 ist.

Nr. 2. B ell gibt in seiner Schrift nicht an, an welcher Thierart er experimentirte. Cl. Bernard hat darauf auch schon hingewiesen. (Rapport sur les progrès et la marche etc. 1. c.)

Nr. 3. Ein entscheidendes Experiment, die alte Lehre, welche die Ganglienknoten als Unterbrecher der Nervenleitung hinstellte, zu stürzen, hat Bell erst später am V. Hirnnerven eines Esels angestellt. Die Nerven mit Ganglienknoten galten früher als "vitale Nerven"; durch die Ganglienknoten sollten sie eben in schwächerem Zusammenhang mit dem Gehirne stehen und die vitalen Bewegungen so unabhängig vom Willen machen.

Nr. 4. Wenn Bell 13 Jahre vorher (es handelt sich um das Jahr 1822) diese Entdeckung gemacht hätte, so wäre das 1809 gewesen. Diese Angabe Shaw's ist unrichtig. (Vgl. Anm. Nr. 1.)

Nr. 5. Nach Longet, Anat. et Physiol. du système nerveux 1842, Bd. I p. 37, hat Magendie im Jahre 1839 in seinen "Leçons sur les fonctions et les maladies du système nerveux, professées au collège de France" angeblich zum ersten Male die rückläufige Sensibilität gelehrt. (Citirt nach Eckbard 1. c.) Wir haben gefunden, dass eine Reihe alter Autoren im Gegensatz zu Longet 1838 als das Entdeckungsjahr ausgibt. - Vgl. ferner: Schiff, Lehrbuch der Muskel- und Nervenphysiologie 1858-1859 S. 144.

Nr. 6. Wir möchten hier auf den etwas unglücklichen Versuch Bell's aus dem Jahre 1824 hinweisen, Magendie gegenüber die Priorität für die Entdeckung der Functionen der Spinalnervenwurzeln zu beanspruchen. Wir haben im Verlauf unserer Untersuchung genau dargethan, inwieweit diese Prioritätsansprüche Bell's berechtigt sind; wir fanden, dass Bell lediglich die motorische Function der vorderen Wurzel vor Magendie lebrte. Alles Uebrige, was Bell ausserdem noch über' die Function der vorderen und hinteren Wurzeln vor Magendie angab, war falsch. Bell macht diese zum grössten Theile ungerechtfertigten Prioritätsansprüche in seinem 1824 erschienenen Buche über das Nervensystem geltend. Wir besitzen nur die französische Uebersetzung dieses Buches aus dem Jahre 1825: „Exposition du système naturel des nerfs du Corps humain, suivie des mémoires sur le même sujet" etc. Folgender Passus aus 
Eine hist. Studie üb. d. Entdeckung d. Magendie-Bell'schen Lehrsatzes. 301

diesem Buche ist bezeichnend: „Après m'être ainsi confirmé (nämlich 1811) dans l'opinion que la colonne antérieure de la moelle épinière et les racines antérieures des nerfs de l'épine sont destinées au monvement, cette conclusion que la colonne postérieure et les racines postérieures appartiennent à la sensibilité, se présentait d'elle-même." (l. c. p. 19.) - Dieser Schluss, 'dass die hinteren Wurzeln sensibel seien, ergab sich, wie wir zeigen konnten, für Bell im Jahre 1811 eben keineswegs von selbst; im Gegentheil zog Bell damals ganz andere Schlüsse über die Function der hinteren Wurzeln! Aber diese Schlüsse aus dem Jahre 1811 verschweigt Bell im Jahre 1824 offenbar absichtlich und sucht durch eine verschleierte Darstellung der Begebenheiten Magendie's unsterbliches Verdienst zu schmälern. - Auch im Jahre 1830 verharrt Bell noch in seiner Schrift: "The nervous System of the human body" etc. (1832 von Romberg in's Deutsche übersetzt) bei dieser sachlich unrichtigen Darstellung der Entdeckungsgeschichte des Gesetzes über die Functionen der Rückenmarksnervenwurzeln und nimmt auch weiterhin für sich den ganzen Ruhm dieser Entdeckung in Anspruch.

Nr. 7. Unter den deutschen Autoren hat, soweit wir uns erinneren, nur Eckhard in seiner erwähnten Abhandlung einen veränderten Namen, „BellMagendie'sches Gesetz", gebraucht.

\section{Literaturverzeichniss.}

1) Vulpian, Leçons sur la physiologie comparée du système nerveux. Paris 1866 p. 105.

2) S. Mayer, Geschichtliche Bemerkungen über den Bell'schen Lehrsatz. Handb. d. Physiologie, herausgegeben von Hermann, Bd. II Theil I p. 226.

3) Claude Bernard, Rapport sur les progrès et la marche de la Physiologie gén. en France. Paris 1867 p. 157.

4) Flint, Considérations historiques sur les propriétés des racines des nerfs rachidiens. Robin, Journal de l'anat. et de phys. 1868 p. 520.

5) Eckhard, Beiträge zur Anatomie und Physiologie 1883. V. Beiträge zur Geschichte der Experimentalphysiologie des Nervensystems. Geschichte der Leitungsverhältnisse in den Wurzeln der Rückenmarksnerven p. 135-169.

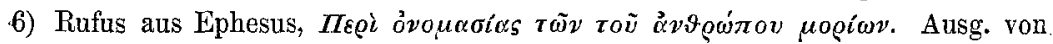
Daremberg-Kuelle. Paris 1879.

7) Galen, De administr. anatom. cap. I. De methodo medendi. - De locis affectis. lib. I. cap. VI. lib. III. cap. XIV. lib. IV. cap. V. und VII.

8) Lamarck, Philosophie zoologique. Bd. II. Du système nerveux p. 180-234. 1809 .

9) Th. Willis, Cerebri anatome cui accessit nervorum descriptio et usus. London 1664. 
10) Walker, Tables of a natural system of medical science. March 1808. Outline of a natural system of medical science. Archives of universal science. 27. October 1808. 1. January, A pril, July 1809. - Sketch of a general theory of the intellectual faculties of man and animals. Thoms on's Journal of philosophy. July and Augus 1815. - The nervous system, anatomical and physiological. London 1834. - An essay on the physiology of the nervous system, with an exposition of claims to priority of discovery etc. The Lancet Nr. 1848 p. 585. Canstatt's Jahresber. 1848 p. 154. (Citirt nach Eckhard l. c.)

11) Charles Bell, F.R.S. E., Idea of a new anatomy of the brain, submitted for the observations of his friends. - Strahan and Preston; Printers-Street, London. (Ueber die Jahreszahl siehe Anm. Nr. 1.)

12) Burdach, Vom Bau und Leben des Gehirns. Bd. I p. 263. 1819.

13) J. Shaw, Masual for the student of anatomy 1821. - London medical and physical Journal. December 1822. (Citirt nach Eckhard und Wefermont)

14) Magendie, Expériences sur les fonctions des racines des nerfs rachidiens. (p. 276.) - Expériences sur les fonctions des racines des nerfs qui naissent de la moelle épinière. (p. 366.) - Journal de Physiologie expérimentale et. pathologique. Tome II. Paris 1822.

15) Fo déra, Recherches expérimentales sur le système nervenx. Académie des sciences. 31. December 1822.

16) Béclard, Elém. d’anat. génér. Paris 1823.

17) Bellingeri, De medulla spinali. Taurin 1823.

18) H. Mayow, Anatomical and physiological commentaries, 1823. Uebersetzung siehe: Journal de Physiologie exp. etc. par F. Magendie, 1828.

19) Amussat. Vgl. Hamburger Magazin Bd. X p. 409. (Citirt nach Eckhard.)

20) Schoeps, Ueber die Verrichtungen verschiedener Theile des Nervensystems. Archiv f. Anat. u. Physiol. von J. F. Meckel. 1827.

21) Rolando, Sperimenti su i fascicoli del midollo spinale. Torino 1823.

22) Backer, Commentatio ad quaestionem physiologicam a facultate medica academiae Rheno-Trajectinae anno 1828 propositam. 1830.

23) Joh. Mủller, Bestätigung des Bell'schen Lehrsatzes, dass die doppelten Wurzeln etc. v. Froriep, Notizen aus dem Gebiete der Natur- und Heilkunde. 1831. - Ferner: Annales des sciences maturelles Tome XXIII. 1831. Ferner: Handb. d. Physiolog. des Menschen Bd. I. 1844.

24) Seubert, Commentatio de functionibus radicum anteriorum et posteriorum nervorum spinalium. 1833.

25) Tiedemann. Citirt nach Eckhard 1. c.

26) Stannius, Hecker's Anmalen 1832.

27) Retzius, Meckel's Archiv 1832.

28) van Deen, De differentia et nexu inter nervos vitae animalis et vitae organicae. Lugd. Bat. 1834.

29) Panizza, Ricerche sperimentali sopra i nervi, Lettera del Prof. Bartolom e o Panizzra al Professore Maurizio Bufalini. Pavia 1834. - Uebersetzung in's Deutsche von C. Schneemann. Frlangen 1836. 
Eine hist. Studie üb. d. Entdeckung d. Magendie-Bell'schen Lehrsatzes. 303

30) Pflüger, Vorläufige Mittheilungen über Einwirkung der vorderen Rückenmarkswurzeln auf das Lumen der Gefässe. Allgemeine med. Centralleitung. 1855 und 1856.

31) Adamkiewicz, Die Secretion des Schweisses. Berlin 1878.

32) Vulpian, Sur la provenance des fibres nerveuses excito-sudorales etc. Compt. rend. hebd. d. séauc. de l'académie des sciences. Tom. LXXVIII. 1878.

33) Stricker, Ueber die Gefässnervenwurzeln der Ischiadicus. Sitzungsber d. math.-nat. Classe der kais. Akademie der Wissensch. LXXIV. 3. Abth.

34) Lenhossék, Ueber Nervenfasern aus den hinteren Wurzeln, welche aus dem Vorderborn entspringen. Anat. Anzeiger V. 1890.

35) Ste in ach, Motorische Functionen hinterer Spinalnervenwurzeln. Pflüger's Archiv Bd. 60. 1896. 